\title{
Effect of Ug99 Race of Stem Rust (Puccinia Graminis F.Sp. Tritici) on Growth and Yield of Barley (Hordeum Vulgare L.) in Kenya
}

\author{
Edward K. Mwando (Corresponding author) \\ Department of Crops Horticulture and Soils, Egerton, University \\ P.O. Box 536, Egerton, Kenya \\ Kenya Agricultural Research Institute, National Plant Breeding Centre \\ P.O. Box Private Bag, Njoro, Kenya \\ Tel: 254-728-453-942_E-mail: edwardmwando@gmail.com \\ Isaiah M. Tabu \\ Department of Crops Horticulture and Soils, Egerton, University \\ P.O. Box 536, Egerton, Kenya \\ Tel: 254-722-105-094Ｅ-mail: masinde@gmail.com \\ Daniel O. Otaye \\ Department of Biological sciences, Egerton, University \\ P.O. Box 536, Egerton, Kenya \\ Tel: 254-723-746-630Ｅ-mail: otayedan@yahoo.com \\ Peter N. Njau \\ Kenya Agricultural Research Institute, National Plant Breeding Centre \\ P.O. Box Private Bag, Njoro, Kenya \\ Tel: 254-717-471-672Ｅ-mail: Njaupnn@yahoo.com
}

Received: December 21, $2011 \quad$ Accepted: January 16, $2012 \quad$ Online Published: April 1, 2012

doi:10.5539/jas.v4n5p161

URL: http://dx.doi.org/10.5539/jas.v4n5p161

\begin{abstract}
Barley stem rust caused by Puccinia graminis f.sp. tritici Eriks. \& E. Henn, was previously contained through the use of genetic resistance resulting from genes such as rpgl but, in 1999 and 2001 a new race Ug99 or TTKSK with virulence to stem rust resistant cultivars carrying resistance gene rpg1, was detected in Uganda and Kenya, respectively. The new variants of Ug99 like PTKST, TTKSF, TTKST and TTTSK with virulence to genes $S r 21$, $\mathrm{Sr} 24$, and $\mathrm{Sr} 36$ of wheat have been detected implying that the race Ug99 is evolving. The experiment was carried out at the Kenya Agricultural Research Institute (KARI) Njoro for two seasons (2008 and 2009) to find out the effect of the new race of Ug99 on the growth and yield of barley. The genotypes included three Kenyan commercial cultivars (Nguzo, Sabini and Karne), two (1512-5 and 1385-13) new introductions from the Kenya malting company and 15 introductions from ICARDA selection. The genotypes were screened for their level of resistance to stem rust disease in the field where each cultivar was sown in plots of $3 \mathrm{~m}$ length at spacing of $20 \mathrm{~cm}$, at seed rate of $125 \mathrm{~kg} \mathrm{ha}^{1}$. The same set was sown as control under fungicides application of tebuconazole (folicur) at $0.75 \mathrm{~L} \mathrm{ha}^{-1}, 3$ times in the season starting at stem elongation stage (Zadoks et al., 1974) at an interval of 21 days. The experimental design was randomized complete block design (RCBD) in split plot arrangement with the main plots as the 20 barley cultivars, while the subplots consisted of fungicide (protected and unprotected), replicated three times. Susceptible wheat cultivars, Chozi was planted perpendicular to test plots in the middle of the 1-m pathways on both sides of experimental plots to serve as spreader. Genotype 1512-5 showed the highest severity of $(93 \%)$ in season 1, while Sabini had the highest severity of 30\% in the second season. Nguzo had the lowest disease severity of $16 \%$ and $5 \%$ in season 1 and 2 , respectively. The highest dry matter loss of 41.1 and $43.1 \%$ was
\end{abstract}


observed in ICARDA-07 and ICARDA-09 in season 1 and 2, respectively. The highest and lowest loss of 67.3\% and $17.8 \%$ in leaf area was recorded on Sabini and 1385-13 in season 1 respectively. Irrespective of season, higher chlorophyll index was noted in treated plots than in untreated ones. Genotypes ICARDA-14 and ICARDA-13 had the highest (45.8\%) and lowest (8.7\%) reduction in number of effective tillers in season 1 . The new race Ug99 (TTKS) of stem rust caused severe loss on the susceptible genotypes. The highest yield loss of $53.8 \%$ was observed in ICARDA- 08 while the lowest loss of $6.9 \%$ was obtained in ICARDA-12 in season 1 . In season 2 the highest loss of $32.1 \%$ was obtained in 1385-13 a Kenyan line. In the present study stem rust Ug99 has a great impact on growth and development of barley. The growth and development factors have an impact on the final yield of the crop and if they are disturbed in the initial stages then they can negatively affect the yield of the crop at the end.

Keywords: Stem Rust Ug99, Barley, Growth and Yield, Kenya, Puccinia Graminis, F.Sp. Tritici, Hordeum Vulgare

\section{Introduction}

Barley is a principal raw material used to process malt, a vital ingredient for beer brewing. The industry is one of the highest corporate taxpayers with annual turnover of Kshs. 28.9 billion and employs more than 1600 people across the region. Rust diseases are among the most widespread and economically important diseases of bBarley worldwide. The fungi that cause these diseases are notorious for their ability to increase rapidly and overcome the resistance. Stem rust or black rust (caused by Puccinia graminis Pers. f. sp. tritici Erikss. \& E. Henn.) is a serious barley disease causing a decrease of barley yield in many areas of the world (Roelfs, 1978). Previously the disease was contained through the use of genetic resistance resulting from genes such as rpgl (CIMMYT, 2005). In 1999 and 2001 in Uganda and Kenya, respectively a new race Ug99 (TTKS) with virulence to stem rust resistant cultivars, was however detected (Wanyera et al., 2006; Pretorius et al., 2000). Preliminary work indicates that race TTKS is virulent on barley cultivars carrying the durable stem rust resistance gene Rpgl (Steffenson and Jin, 2006). More recently stem rust races Ug99 variants like PTKST, TTKSF, TTKSK, TTKSP, TTKST and TTTSK, with virulence to genes $S r 21$, Sr24, and $S r 36$ of wheat imply that the race Ug99 is evolving (Jin et al., 2009; Jin et al., 2008b; Jin et al., 2008, and Jin et al., 2007). The variants caused severe epidemics and rendered about half of the previously known Ug99-resistant global wheat materials susceptible in Kenya. The experiment was conducted to determine the effect of stem rust race Ug99 on the growth and yield of barley.

Keywords: Stem rust, Barley, Growth and development, Ug99, Puccinia graminis f. sp. tritici, Yield

\section{Materials and Methods}

\subsection{Site Description}

The experiment was carried out at the Kenya Agricultural Research Institute (KARI) Njoro for two seasons (2008/09). KARI -Njoro situated along the Njoro-Mau Narok road in Nakuru County, located at $0^{0} 20^{\prime} \mathrm{S} 35^{0} 56^{\prime} \mathrm{E}$ and at 2185 meters above sea level. It receives an average rainfall of $939 \mathrm{~mm}$ per annum, with a mean temperature range of $9.5^{\circ} \mathrm{C}$ to $24^{\circ} \mathrm{C}$ and falls within the agro-ecological zone III (Jaetzold and Schmidts, 1983).

\subsection{Germplasm Used}

Twenty barley germplasm that included three Kenyan commercial cultivars (Nguzo, Sabini and Karne), two (1512-5 and 1385-13) new introductions from the Kenya malting company and 15 selections from ICARDA were used.

\subsection{Experimental Design}

Each cultivar was sown in plots of $3 \mathrm{~m}$ length at spacing of $20 \mathrm{~cm}$, at seed rate of $125 \mathrm{~kg} \mathrm{ha-}^{-1}$. The same set was sown as control under fungicides application of tebuconazole (folicur) at $0.75 \mathrm{~L} \mathrm{ha}^{-1}, 3$ times in the season starting at stem elongation stage (Zadoks et al., 1974) at an interval of 21 days. The experimental design was randomized complete block design (RCBD) in split plot arrangement with the main plots as the 20 barley cultivars while the subplots consisted of fungicide (protected and unprotected), replicated three times. Susceptible wheat cultivars, Chozi was planted perpendicular to test plots in the middle of the $1-\mathrm{m}$ pathways on both sides of experimental plots to serve as spreader. The spreader rows were inoculated with $P$. g. tritici pathotype TTKSK at the early jointing stage by injecting an aqueous suspension of urediniospores into the hollow culm of plants at 0.75 -m intervals along each spreader. The spores used for inoculation were collected from experimental plots in KARI-Njoro on wheat cultivar Chozi. The inoculum was pre-tested on differential hosts in the greenhouse according to Roelfs et al. (1989) and confirmed to be those of PgtUg99.

\subsection{Crop Management}

A basal dose of DAP fertilizer $\left(18 \% \mathrm{~N}\right.$ and $\left.46 \% \mathrm{P}_{2} \mathrm{O}_{5}\right)$ at a rate of $50 \mathrm{~kg} \mathrm{ha-}{ }^{1}$ was applied at planting and followed with a top dress of CAN $(23 \% \mathrm{~N})$ at $25 \mathrm{~kg}$ ha- ${ }^{-1}$ a month later. Weeds were controlled using Stomp 500E, a 
pre-emergency herbicide at a rate of 3.0 $\mathrm{L} \mathrm{ha}^{-1}$. Buctril MC (bromoxyil and iso-octyl esters) a post emergent herbicide was applied at the rate of $1.25 \mathrm{~L} \mathrm{ha}^{-1}$ to control broad-leaved weeds (KARI, 2005a). Metasystox insecticide at the rate of $0.75 \mathrm{~L} \mathrm{ha}^{-1}$ was used to control Russian wheat aphid (RWA) and other insect pests.

\subsection{Data Collection}

The infection type responses as described by Roelfs et al. (1992), McIntosh et al. (1995) and disease severities $0-100 \%$, Peterson et al. (1948) were recorded in both trials starting from when $50 \%$ of the plants reached heading stage at an interval of 14 days until hardening stage. Final disease severity (FDS) score was taken at hardening. The disease was assessed as the incidence of plant infected with stem rust in a cultivar, and the percent of the disease severity (modified cobb scale) was used to calculate the area under disease progress curve (AUDPC) of each cultivar as described by Shaner and Finney (1977) and Mwandemele (1993). Chlorophyll index was taken after every two weeks on the flag leaf of three plants in the plot selected at random using a chlorophyll meter and the average was calculated. The tillering capacity was determined by counting the number of spikes per meter squared.

Harvesting was done after physiological maturity to ensure all the spikes were sufficiently dry for harvesting. A half meter square quadrant was thrown in the middle of each plot and a fifty tillers harvested by cutting them at the ground level using a sickle and put into a labeled paper bag for subsequent drying in an oven at $65^{\circ} \mathrm{C}(48 \mathrm{~h})$ until constant weight and weighed at $13 \%$ moisture content. The spikes from each plot were fed into a portable thresher and winnowed. The 1000-kernel weight was determined after counting the grain with an electric seed counter (Model: PFEUFFER GmbH FlugplatzstraBe70D-97318 Kitzingen). The yield of the whole plot was determined by harvesting the whole plot and threshing them. The grain yield loss for each cultivar was calculated by subtracting the yield of untreated plot from the treated and then divided by the yield of treated plot multiplied by 100 . The grain shriveling was determined by sampling grains from each plot and screening them through $2.5 \mathrm{~mm}$ sieve.

\section{Results and Discussions}

\subsection{Stem Rust Development and Expression of Resistance}

\subsubsection{Field Disease Severity}

The mean final disease severity (FDS) was higher in season 1 compared to season 2 (Table 1). This may be attributed to the higher relative humidity and warmer temperatures in season 1 . The area under disease progress curve (AUDPC) varied with season and genotypes. The highest final disease was noted in 1512-5 and Sabini in season 1 and 2, respectively. 1385-13 had the highest AUDPC in season 1, while ICARDA-01 had the lowest in season 2 . The variation in disease progress may be attributed to genotype and phenotype differences of plant types. Fast rusting genotypes are generally associated with high disease progress and final disease rating. Similarly, Lal et al. (2004) found a relationship in values for final diseases and AUDPC in slow rusting and susceptible cultivars among barley genotypes. The slow rusting ability is due to the effect of a combination of genes working together against the disease. According to Kleinhofs et al. (2009) the rpg4 and rpg5 genes confer resistance to several wheat stem rust races, including TTKSK that is threatening the world wheat and barley. Harder et al. (2000) confirmed that lines with gene combinations of $\mathrm{rpg} 1 / \mathrm{rpg} 3$ and $\mathrm{rpg} 1 / \mathrm{rpg} 4$ provided a highest level of protection to stem rust epidemic than those with $\mathrm{rpg} 1 / \mathrm{rpgU}$ combination. Season is an important factor in disease development where the season is conducive for the disease we expect high score for final disease and large area under disease development curve that is why season was significant for all genotypes regardless of the disease reaction.

\subsection{Effect of Stem Rust on Growth and Growth Components}

\subsubsection{Dry Matter}

A mean dry matter loss of 20.7 and $23.0 \%$ attributed to stem rust Ug99 was observed in season 1 and 2, respectively. The highest dry matter loss of 41.1 and $43.1 \%$ was observed in ICARDA-07 and ICARDA-09 in season 1 and 2, respectively (Table 2). Harder and Legge (2000) similarly found dry matter reduction of up to $25.5 \%$ under natural infection of stem rust. In addition to the effect on dry matter, the rust pathogen also affects the translocation patterns of the photosynthates, which are preferentially directed toward the infected zones where they are used up by the rust pathogen at the expense of the host growth and development (Bushnell and Roelfs, 1984). Durbin (1967) reported that the rusted host had higher respiration rates and depressed photosynthesis that led to reduction in growth and accumulation of dry matter.

\subsubsection{Leaf Area}

The leaf area was higher in treated plots than in untreated ones in both seasons (Table 2). In season 1 the highest and lowest loss of $67.3 \%$ and $17.8 \%$ was recorded on Sabini and 1385-13, respectively. In season two ICARDA-14 and ICARDA-08 had the highest (35.1\%) and lowest (8.9\%) amount of losses, respectively. The reduction in the 
photosynthetic leaf area was attributed to flaking (Bushnell and Roelfs, 1984). Extensive pustule cover on the stems and leaves, compiled with reduced leaf surface area hence light interception and photosynthesis, could have affected plant performance.

\subsubsection{Chlorophyll Index}

Irrespective of season, higher chlorophyll index was noted in treated plots than in untreated ones (Table 2). The highest chlorophyll losses of 56.2\% in Nguzo and 54.9\% in 1512-5 were noted in season 1 and 2, respectively. Herrera-Foessel et al. (2006) attributed the reduction in chlorophyll content to the hypersensitive reaction on the leave sheaths. Owere et al. (1981) found the loss of chlorophyll to be the principal limiting factor of photosynthesis in barley affected by leaf rust. Increase in ethylene and abscisic acid content of stem rust infected wheat could promote senescence and premature yellowing of healthy leaves (Harder et al., 1984). Gordon and Duniway (1982); Tani et al. (1973) reported a reduction in amount of ribosomal RNA in an oat infected with crown rust suggesting that synthesis of chloroplast protein may be generally depressed by rust infections.

\subsubsection{Tillering Capacity}

The numbers of effective tillers in protected plots were higher than those in unprotected ones across the seasons (Table 2). Genotypes ICARDA-14 and ICARDA-13 had the highest (45.8\%) and lowest (8.7\%) reduction in number of effective tillers in season 1, respectively. In season 2, 1385-13 had a loss of 24\% and selection ICARDA-13 with $1.7 \%$. Plant processes are generally intimately related. Changes in photosynthates distribution induced by localized infections of rust fungi will have physiological and metabolic repercussion in other parts of the plant and at later times in its development (Agrios, 2005). Bushnell and Rowell (1968) found that in severely rusted wheat shoot desiccation and death led to a drastic decline in the roots capacity to water absorption. Tillering capacity is a function of availability of adequate photosynthates and ideal environment.

\subsubsection{Plant Height}

Plant height is an important proxy of growth, variation of plant height is a function of genotype and season. In season 1, a significant loss in plant height in selections ICARDA-07, ICARDA-04, ICARDA-11, ICARDA-13 and Nguzo was noted. In season 2, ICARDA-03, 1385-13 and KARNE had the highest loss in height (Table 2). Harder and Legge (2000), however found no reduction in plant height caused by stem rust in barley. The difference could be as a result of factors like the stage of plant development at the time of infection, location of infection on the plant, and the environmental condition can modify the magnitude of the effect. Corver and Griffiths (1981) noted that the imbalance created during the early plant growth by diseases like powdery mildew and rusts can have particular large effect on the plant height and number of tillers.

\subsection{Effect of Stem Rust Ug99 on Yield and Yield Components}

\subsubsection{Total Grain Yield}

The new race Ug99 (TTKS) of stem rust caused severe loss on the susceptible genotypes (Table 3). The highest yield loss of $53.8 \%$ was observed in ICARDA- 08 while the lowest loss of $6.9 \%$ was obtained in ICARDA-12 in season 1. In season 2 the highest loss of $32.1 \%$ was obtained in 1385-13, a Kenyan line. The rapid disease progression on susceptible cultivars was exhibited in the extensive yield losses. This means that when environmental conditions are ideal for proliferation and rapid progression of stem rust, reduction in crop yields would be expected. Dill-Macky et al. (1990) in Australia similarly reported a reduction in yield ranging from 20 to $60 \%$ caused by stem rust. Loughman et al. (2005) reported that stem rust can cause yield losses irrespective of the level of resistance. Generally plants respond to infection using energy - demanding physiological processes, such as defense reaction hence the yield declines (Smedegaard-Petersen and Tolstrup, 1985). The fungicides increase the yields of the treated cultivars through protection against the disease and/or phytotonic effect. Ransom et al. (2008) found that there was an increase in yield of hard winter wheat cultivars. The fungicides also increased the days to senescence, the grain filling and ultimately the yield (Burgeno et al., 2000). Yang (et al. 2000) reported that fungicides increased yield by $0.25 \%$ when used to control stem rust disease in barley. This explains the increase in yield in protected plots across the season, especially in the first season. Mayfield (1985) found a clear relationship between grain yield and disease severity and demonstrated that increasing stem rust severity by about $1 \%$ increased grain loss by $2 \%$. Most of the barley germplasm did not show significant reduction in kernel weight. The grain yield loss in susceptible cultivars was attributed to interruption in movement of photosynthates, water and minerals caused by wheat stem rust (Agrios, 2005).

\subsubsection{Thousand Kernel Weight}

A thousand kernel weight was higher in treated plots than in untreated ones in both seasons. The highest loss (14.8\%) was associated with the disease on Sabini in season 1 (Table 3). Harder and Legge (2000) similarly 
reported a loss ranging from $7-43 \%$ in kernel weight in barley for resistant and susceptible varieties, respectively. Herrera-Foessel et al. (2006) reported an average loss in kernel weight of 13.3 and $10.3 \%$ in durum wheat for normal- and late-sown trials, respectively; hence, the average kernel weight was reduced irrespective of rust pressure in the late sown trial. Gaunt (1981) described tolerance as the ability of the plant to maintain desirable yield, quality and performance in the presence of the disease symptom or if the plant appears susceptible to the disease. The 1000 kernel weight is not likely to describe disease effects on the yield than the yield measurement itself, because they were not consistent across the seasons.

\subsubsection{Grain Size}

Grain size is an important parameter of yield and quality of any crop. Grains from untreated plots passed through the $2.5 \mathrm{~mm}$ sieve than from the treated plots (Table 3). The highest loss of $69 \%$ in $1512-5$ and $49.5 \%$ in ICARDA09 was recorded in the two seasons respectively. The genotype 1512-5 had the highest loss, final disease and second last area under disease progress curve in season 1 that was not the case for ICARDA- 09 in season 2. The reduction in the grain size can be greatly attributated to the negative effect of stem rust on grain filling process. Calpouzos et al. (1976) and Johnson and Wilcoxson (1979) attributed, reduction in grain size and weight had been associated with stem rust of wheat and barley leaf rust caused by Puccinia hordei). The disease affects the photosynthates partitioning to the grain, reducing the size and adversely affecting the quality of barley. Barley grains of different sizes vary in malting behavior and produce malts with different properties (Burger and La Berge, 1985). The small grains from rusted plants were generally unsuitable for the production of malt. When infection occur during critical periods such as anthesis or grain filling, productivity can be drastically curtailed because the maturation period is reduced hence the reduced grain size (Bushnell and Roelfs, 1984).

\section{Conclusions}

In the present study stem rust Ug99 has been found to have a great impact on growth and development of barley. Despite the fact that most of the barley genotypes were affected by the disease some did not show a high final disease and AUDPC that was reflected in the reduced losses of the growth and development aspects of the respective genotypes. This was mainly attributed to the slow rusting factor in the genotypes. The growth and development factors have an impact on the final yield of the crop and if they are disturbed in the initial stages then they can affect the yield of the crop at the end. Season and genotype are also important factors that affect pressure of the diseases and hence the growth and development.

\section{Acknowledgements}

The assistance that was accorded to us by the staff of KARI Njoro is greatly appreciated. We are also grateful to East Africa malting company for the genotypes that were used in part of this study. Egerton University is appreciated for the funding of the project.

\section{References}

Agrios, G. N. (2005). Plant pathology $5^{\text {th }}$ edition. Academic press, San Diego U.S.A. pp 565-571.

Burgeon, J., Cadena, A. R., Crossa, J., Banzinger, M., Gilmour, A. R. \& Cullis, B. R. (2000). User's Guide for Spatial Analysis of Field Variety Trial using ASREML, CIMMYT, Mexico. D.F.

Burger, W. C., \& La Burge, D. E. (1985). Malting and brewing quality. In 'Barley'. (Ed.D.C. Rasmusson.) Agronomy Series, 26, $367-401$.

Bushnell W. R., \& Roelfs, A. P. (1984). The cereal rusts. Vol 1. Origins, specificity, structure, and physiology. Academic press. Orlando, pp. $333-373$.

Bushnell, W. R., \& Rowell, J. B. (1968). Premature death of adult rusted wheat plant in relation to carbon dioxide evolution by root systems. Phytopathology, 58, $651-258$.

Calpouzos, L., Roelfs, A. P., Madson, Martin, F. B., Welsh, J. R., \& Wilcoxson, R. D. (1976). Anew model to measure yield losses caused by stem rust in spring wheat. Trends of British Mycological Society, 55, 467 - 479.

CIMMYT. (2005). Sounding the Alarm on Global Stem Rust. An Assessment of Ug99 in Kenya and Ethiopia and Potential for Impact in neighboring Regions and beyond. 29 May 2005. pp 26.

Dill - Macky, R. Rees, R. G., \& Platz, G. J., (1990). Stem rust epidemics and their effects on grain yield and quality in australian barley cultivars. Australian journel of agricultural research, 41, 1057 - 1063.

Durbin, R. D. (1967). Obligate parasite: effect on the movement of solutes and water. In The dynamic role of molecular constituents in plant - parasite interactions C.J. Mirocha and I. Uritani, edititors, pp.80-99. 
Fox, S. L., \& D. E. Harder. (1995). Resistance to stem rust in selected barley lines and the inheritance of resistance to pathotype QCC. Canadian Journal of Plant Science, 75, 781-788.

Gaunt, R. E. (1981). Disease tolerance - an indicator of threshold? Phytopathology, 71, 915 - 916.

Gordon, T. R. \& Duniway, J. M. (1982). Effects of Powdery Mildew Infection on The Effects of Co2 Fixition and Light Utilization On Sugar Beet Leaves. Plant Physiology, 69, 139 - 142.

Harder, D. E, \& Chong, J. (1984). Structure and physiology of haustoria. In Bushnell WR, Roelfs AJ, eds. 1984. The Cereal Rusts, Vol. 1. Origins, Specificity, Structure, and Physiology. New York, pp. 431-76.

Harder, D. E., \& Legge, W. G. (2000). Effectiveness of different sources of stem rust resistance in barley. Crop science, $40,826-833$.

Herrera-Foessel, S. A., Singh, R. P., Huerta-Espino, J., \& Djurle, A. (2006). Effect of Leaf Rust on Grain Yield and Yield Traits of Durum Wheats with Race-Specific and Slow-Rusting Resistance to Leaf Rust. Plant Disease, 90, 1065-1072.

Jaetzold, R., \& Schmidt, H. (1983). Farm management handbook of Kenya. Vol. II Natural condition and farm management information. Ministry of Agriculture, Kenya in cooperation with Germany Agricultural team (GAT) of the Germany Agency for technical cooperation (GTZ) Nairobi Kenya Pp. 345.

Jin, Y., Rouse, M.N., Fetch Jr, T., Pretorius, Z. A., Wanyera, R., \& Njau, P. (2009). Detection of virulence to resistance gene Sr36 within the TTKS race lineage of Puccinia graminis f. sp. tritici. Plant Disease, 93, 367-370. http://dx.doi.org/10.1094/PDIS-93-4-0367

Jin, Y., Pretorius, Z. A., Singh, R. P., \& Fetch Jr, T. (2008a). Detection of virulence to resistance gene $S r 24$ within race TTKS of Puccinia graminis f. sp. tritici. Plant Disease, 92, 923-926. http://dx.doi.org/10.1094/PDIS-92-6-0923

Jin, Y., Szabo, L., \& Pretorius, Z. A. (2008b). Virulence variation within the Ug99 lineage. In: Proceedings of the 11th International Wheat Genetics Symposium, Brisbane, Australia Pp. 342.

Jin Y, Pretorius Z. A, \& Singh, R. P. (2007). New virulence within race TTKS (Ug99) of the stem rust pathogen and effective resistance genes. Phytopathology, 97, 137 - 143.

Jin, Y., Steffenson, B. J., \& Miller, J. D. (1994). Inheritance of Resistance to Pathotypes QCC and MCC of Puccinia graminis f. sp. tritici. In barley lines Q21861 and Temperature Effect on the Expression of Resistance. Phytopathology, 84, $452-455$.

Johnson, D. A., \& Wilcoxson, R. D. (1979). Yield losses of fast and slow rusting barley infected with Puccinia hordei. Plant Disease Report, 63, $764-768$.

Kenya Agriculture Institute (KARI). (2005a). Crop production hand book for wheat, oil crops and horticulture. Kinyua,M.G. and Ochieng, J. A. W. (Eds.). G. Gansdil printers \& stationary, Nairobi, Kenya. Pp 1 - 19.

Kenya Agricultural Research Institute (KARI). (2005b). Effect of a new race on wheat production/use of fungicides and its cost in large vs. small scale farmers, situation of current cultivars. KARI, Njoro. Pp 1- 102.

Kleinhofs, K., Brueggeman, R., Nirmala, J., Zhang, L., Mirlohi, A., Druka, A., Rostocks, N., \& Steffenso B. J. (2009). Barley stem rust resistance genes: Structure and function. The plant genome, 2 (2), 109-120.

Loughman, R., Jayasena, K., \& Majewski. J. (2005). Yield Loss and Fungicide Control of Stem Rust of Wheat. Australian Journal of Agricultural Research, 56, 323 - 327.

Mayfield, A. H. (1985). Efficacies of fungicides for control of stem rust of wheat. Australia Journal of Agriculture, $25,440-443$.

McIntosh, R. A., Wellings, C. R., \& Park, R. F. (1995). Wheat Rusts. An Atlas of Resistance genes. (CSIRO Publications, East Melbourne, Australia).

Mwandemele, O. D. (1993). Hand book of plant breeding, $2^{\text {nd }}$ Ed, EMC, Egerton university, Njoro, Kenya. Pp 90-110.

Owera, S. A. P., Farrar, J. F., \& Whitbread, R. (1981). Growth and photosynthesis in barley infected with brown rust. Physiology of plant pathology, 18, $79-90$.

Peterson, R. F., Campbell, A. B., \& Hannah, A. E. (1948). A diagramic scale for estimating rust intensity of leaves and stems cereals. Canadian Journal of Research, 26, 496-600. 
Pretorius, Z. A., \& Park, R. F. (2008). Origin, evolution, distribution and virulence of Ug99 and the global stem rust monitoring system. In: International Conference on Wheat Stem Rust Ug 99- A Threat to Food Security. November $6^{\text {th }}-8^{\text {th }}, 2008$. NewDelhi, India.

Pretorius, Z. A., Singh, R. P., Wagoire, W. W., \& Payne, T. S. (2000). Detection of virulence to wheat stem rust resistance genes Sr31 in Puccinia graminis f. sp. tritici in Uganda. Plant Disease, 84, 203. http://dx.doi.org/10.1094/PDIS.2000.84.2.203B

Ransom, J. K., \& McMullen, M. V. (2008). Yield and Disease Control on Hard Winter Wheat Cultivar with Folior Fungicides. Agronomy Journal, 100, 1130 - 1137. http://dx.doi:10.2134/agronj2007.0397

Roelfs, A. P., Singh, R. P., \& Saari, E. E. (1992). Rust Diseases of Wheat: Concepts and Methods of Disease Management. Mexico, DF: CIMMYT.

Roelfs, A. P., \& Martens, J. W. (1989). An international system of nomenclature for Puccinia graminis f. sp. tritici. Phytopathology, 78, 526-533.

Roelfs, A. P. (1978). Estimated losses caused by rust in small grain cereals in the United States-1918-76. Misc. Publ.-U.S., Dep. Agric., 1363, 1-85.

Shaner, G., \& Finney, R. E. (1977). The effect of nitrogen fertilizer on the expression of slow-mildew resistance in Knox wheat. Phytopathology, 67, $1051-56$.

Smedegaard - Peterson, V., \& Tolstrup, K. (1985). The Limiting Effects of Disease Resistance on Yield. Annual Review of Phytopathology, 23, $475-490$.

Steffenson, B. J., \& Jin, Y. (2006). Resistance to race TTKS of Puccinia graminis f. sp. tritici in barley. Phytopathology, 96, $110-115$.

Wanyera, R., Kinyua, M. G., Jin, Y., \& Singh R. P. (2006). The spread of stem rust caused by Puccinia graminis f. sp. tritici, with virulence on $S r 31$ in wheat in Eastern Africa. Plant Disease, 90, 113-117. http://dx.doi.org/10.1094/PD-90-0113A

Zadoks, J. C., Chang, T. T. \& Konazak, C. F. (1974). A decimal code for growth stages of cereals. Weed research, $14,415-421$.

Table 1. The final disease severity (FDS\%) and area under disease progress curve (AUDPC) of barley genotypes

\begin{tabular}{|c|c|c|c|c|}
\hline & FDS $\%^{x}$ & & $\operatorname{AUDPC}^{\mathbf{Y}}$ & \\
\hline Genotypes code/ Name & Season1 & Season2 & Season1 & Season2 \\
\hline ICARDA- 01 & $23^{*} \mathrm{MR}^{* *}$ & $7 \mathrm{MR}$ & $800.3 \pm 171 . .36^{\mathrm{fgh}}$ & $51.7 \pm 25.85^{d}$ \\
\hline ICARDA- 02 & $28 \mathrm{~S}$ & $6 \mathrm{~S}$ & $825.3 \pm 247.08^{\mathrm{fgh}}$ & $162.7 \pm 89.25^{\mathrm{bcd}}$ \\
\hline ICARDA- 03 & $56 \mathrm{~S}$ & $18 \mathrm{~S}$ & $1828.3 \pm 134.89^{\text {cde }}$ & $479.0 \pm 210.32^{\mathrm{abc}}$ \\
\hline ICARDA- 04 & 46S-MS & $13 \mathrm{MS}$ & $1713.7 \pm 337.20^{\text {cde }}$ & $323.3 \pm 119.66^{\mathrm{abcd}}$ \\
\hline ICARDA- 05 & $41 \mathrm{~S}$ & $13 \mathrm{~S}$ & $1732.0 \pm 549.10^{\text {cde }}$ & $280.0 \pm 67.69^{\mathrm{abcd}}$ \\
\hline ICARDA- 06 & $23 \mathrm{MS}$ & $9 \mathrm{MS}$ & $608.3 \pm 143.73^{\mathrm{h}}$ & $179.7 \pm 105.28^{\mathrm{bcd}}$ \\
\hline ICARDA -07 & 40MS-S & $16 \mathrm{MS}$ & $1573.3 \pm 120.58^{\text {cdef }}$ & $325.0 \pm 105.01^{\mathrm{abcd}}$ \\
\hline ICARDA- 08 & $45 \mathrm{~S}$ & $16 \mathrm{MS}$ & $1676.0 \pm 145.10^{\text {cde }}$ & $401.67 \pm 100.29^{\mathrm{abcd}}$ \\
\hline ICARDA- 09 & $53 \mathrm{~S}$ & $15 \mathrm{~S}$ & $1696.0 \pm 82.97^{\mathrm{cde}}$ & $410.0 \pm 212.20^{\mathrm{abcd}}$ \\
\hline ICARDA- 10 & 46MS & $15 \mathrm{MS}$ & $1541.0 \pm 295.10^{\mathrm{def}}$ & $310.0 \pm 101.15^{\mathrm{abcd}}$ \\
\hline ICARDA -11 & $73 \mathrm{~S}$ & $13 \mathrm{~S}$ & $2358.3 \pm 106.27^{\mathrm{abc}}$ & $400.3 \pm 152.43^{\mathrm{abcd}}$ \\
\hline ICARDA -12 & $50 \mathrm{~S}$ & $15 \mathrm{~S}$ & $1494.3 \pm 286.01^{\mathrm{defg}}$ & $360.3 \pm 49.21^{\mathrm{abcd}}$ \\
\hline ICARDA- 13 & $63 \mathrm{~S}$ & $21 \mathrm{~S}$ & $2186.0 \pm 70.71^{\mathrm{bcd}}$ & $559.3 \pm 126.54^{\mathrm{ab}}$ \\
\hline ICARDA- 14 & $20 \mathrm{MS}$ & $6 \mathrm{MS}$ & $654.7 \pm 157.31^{\mathrm{h}}$ & $128.0 \pm 75.97^{\mathrm{cd}}$ \\
\hline ICARDA- 15 & $36 \mathrm{~S}$ & $16 \mathrm{~S}$ & $1551.7 \pm 12.26^{\mathrm{def}}$ & $436.7 \pm 92.90^{\mathrm{abcd}}$ \\
\hline $1385-13$ & $86 \mathrm{~S}$ & $16 \mathrm{~S}$ & $2992.7 \pm 54.36^{\mathrm{a}}$ & $345.0 \pm 139.54^{\mathrm{abcd}}$ \\
\hline NGUZO & 16R-MR & $5 \mathrm{MR}$ & $755.3 \pm 220.72^{\mathrm{gh}}$ & $84.0 \pm 77.09^{\mathrm{cd}}$ \\
\hline $1512-5$ & $93 \mathrm{~S}$ & $21 \mathrm{~S}$ & $2756.7 \pm 206.82^{\mathrm{ab}}$ & $559.3 \pm 130.18^{\mathrm{ab}}$ \\
\hline KARNE & 46R-MR & $13 \mathrm{MR}$ & $1174.7 \pm 417.31^{\text {efgh }}$ & $186.0 \pm 86.02^{\mathrm{bcd}}$ \\
\hline SABINI & $63 \mathrm{~S}$ & $30 \mathrm{~S}$ & $2067.7 \pm 538.30^{\mathrm{cd}}$ & $616.0 \pm 105.55^{\mathrm{a}}$ \\
\hline
\end{tabular}

${ }^{X}$ Final disease severity (FDS \%) last rating following the modified Cobb scale (Peterson et al., 1948). ${ }^{Y}$ Area under disease progress curve (AUDPC).Any two means in a column whose SE values overlap are not different at $\alpha=0.05$ by DMRT. "Means followed by the same letter in column are not significantly different at ( $p \leq 0.05)$ 
Table 2. Effect of stem rust infection on growth and growth components of barley genotypes

\begin{tabular}{|c|c|c|c|c|c|c|c|c|c|c|}
\hline & $\begin{array}{c}\text { Dry Matter } \\
(\mathbf{K g})\end{array}$ & & $\begin{array}{c}\text { Leaf area } \\
(\mathrm{cm})\end{array}$ & & $\begin{array}{c}\text { Chlorophyll } \\
\text { index }\end{array}$ & & Tillers $\mathbf{m}^{-2}$ & & $\begin{array}{c}\text { Height } \\
(\mathrm{cm})\end{array}$ & \\
\hline \multirow[b]{2}{*}{$\begin{array}{l}\text { Genotypes } \\
\text { code/ Name }\end{array}$} & Season1 & Season 2 & Season 1 & Season 2 & Season1 & Season2 & Season 1 & Season2 & Season1 & Season 2 \\
\hline & Mean \%Loss & Mean \%Loss & Mean \%Loss & Mean \%Loss & Mean \%Loss & Mean \%Loss & Mean \%Loss & Mean \%Loss & Mean \%Loss & Mean \%Loss \\
\hline ICARDA-01 & $25.6 \pm 13.35^{\mathrm{abc}}$ & $26.9 \pm 11.91^{\mathrm{abc}}$ & $42.0 \pm 5.53^{\mathrm{abc}}$ & $30.5 \pm 4.32^{\mathrm{a}}$ & $18.2 \pm 5.29^{\mathrm{cd}}$ & $22.4 \pm 2.16^{\mathrm{ab}}$ & $15.4 \pm 5.74^{\mathrm{bcd}}$ & $11.2 \pm 4.71^{\mathrm{ab}}$ & $7.8 \pm 4.42^{\mathrm{abcd}}$ & $4.7 \pm 3.59^{\mathrm{b}}$ \\
\hline ICARDA-02 & $22.3 \pm 1.03^{\mathrm{abc}}$ & $16.3 \pm 2.42^{\mathrm{abc}}$ & $42.3 \pm 8.33^{\mathrm{abc}}$ & $20.8 \pm 6.96^{\mathrm{ab}}$ & $37.7 \pm 7.42^{\text {abcd }}$ & $24.6 \pm 16.16^{\mathrm{ab}}$ & $19.4 \pm 6.58^{\mathrm{bcd}}$ & $9.2 \pm 6.77^{\mathrm{ab}}$ & $3.3 \pm 1.38^{\mathrm{d}}$ & $1.1 \pm 1.45^{\mathrm{b}}$ \\
\hline ICARDA-03 & $14.7 \pm 10.83^{\mathrm{bc}}$ & $16.7 \pm 5.09^{\mathrm{abc}}$ & $44.6 \pm 15.55^{\mathrm{abc}}$ & $10.9 \pm 3.66^{\mathrm{ab}}$ & $21.0 \pm 9.13^{\mathrm{bcd}}$ & $13.3 \pm 6.41^{b}$ & $26.6 \pm 10.61^{\mathrm{abcd}}$ & $11.6 \pm 3.90^{\mathrm{ab}}$ & $9.7 \pm 3.77^{\mathrm{abcd}}$ & $7.9 \pm 4.57^{\mathrm{ab}}$ \\
\hline ICARDA-04 & $26.7 \pm 13.50^{\mathrm{abc}}$ & $25.6 \pm 15.18^{\mathrm{abc}}$ & $46.7 \pm 20.17^{\mathrm{abc}}$ & $30.8 \pm 16.73^{\mathrm{a}}$ & $20.8 \pm 12.49^{\mathrm{bcd}}$ & $27.3 \pm 10.46^{\mathrm{ab}}$ & $22.7 \pm 5.86^{\mathrm{abcd}}$ & $21.2 \pm 6.14^{\mathrm{a}}$ & $12.6 \pm 6.10^{\mathrm{abc}}$ & $1.2 \pm 1.29^{\mathrm{b}}$ \\
\hline ICARDA-05 & $17.7 \pm 3.77^{\mathrm{bc}}$ & $9.0 \pm 4.13^{\mathrm{c}}$ & $21.4 \pm 10.20^{\mathrm{bc}}$ & $31.9 \pm 2.48^{\mathrm{a}}$ & $29.4 \pm 7.41^{\mathrm{abcd}}$ & $26.4 \pm 11.76^{\mathrm{ab}}$ & $36.1 \pm 15.61^{\mathrm{abc}}$ & $9.1 \pm 3.34^{\mathrm{ab}}$ & $8.1 \pm 2.65^{\text {abcd }}$ & $2.0 \pm 1.88^{\mathrm{b}}$ \\
\hline ICARDA-06 & $31.5 \pm 8.04^{\mathrm{bc}}$ & $34.5 \pm 5.12^{\mathrm{abc}}$ & $31.4 \pm 14.62^{\mathrm{bc}}$ & $16.1 \pm 4.94^{\mathrm{ab}}$ & $17.6 \pm 7.46^{\mathrm{cd}}$ & $39.3 \pm 16.17^{\mathrm{ab}}$ & $39.9 \pm 10.40^{\mathrm{ab}}$ & $22.8 \pm 2.82^{\mathrm{a}}$ & $8.9 \pm 1.47^{\mathrm{abcd}}$ & $1.9 \pm 1.76^{\mathrm{b}}$ \\
\hline ICARDA-07 & $41.1 \pm 9.06^{\mathrm{a}}$ & $41.3 \pm 10.21^{3 a}$ & $34.6 \pm 9.85^{\mathrm{bc}}$ & $19.8 \pm 12.41^{\mathrm{ab}}$ & $33.0 \pm 15.35^{\mathrm{abcd}}$ & $17.6 \pm 9.66^{b}$ & $20.4 \pm 5.54^{\mathrm{bcd}}$ & $23.3 \pm 11.56^{\mathrm{a}}$ & $13.7 \pm 5.31^{\mathrm{a}}$ & $13.2 \pm 3.51^{\mathrm{a}}$ \\
\hline ICARDA-08 & $18.7 \pm 5.82^{\mathrm{abc}}$ & $13.0 \pm 4.21^{\mathrm{bc}}$ & $47.2 \pm 8.08^{\mathrm{ab}}$ & $35.1 \pm 10.55^{\mathrm{a}}$ & $14.3 \pm 4.96^{\mathrm{d}}$ & $24.9 \pm 7.38^{\mathrm{ab}}$ & $30.9 \pm 18.71^{\text {abcd }}$ & $20.6 \pm 11.42^{\mathrm{a}}$ & $13.3 \pm 2.68^{\mathrm{ab}}$ & $0.2 \pm 1.03^{\mathrm{b}}$ \\
\hline ICARDA-09 & $16.7 \pm 9.55^{\mathrm{bc}}$ & $43.1 \pm 18.90^{\mathrm{a}}$ & $42.6 \pm 5.91^{\mathrm{abc}}$ & $19.1 \pm 7.12^{\mathrm{ab}}$ & $38.7 \pm 7.23^{\mathrm{abcd}}$ & $24.9 \pm 19.70^{\mathrm{ab}}$ & $27.2 \pm 13.62^{\mathrm{abcd}}$ & $15.1 \pm 6.30^{\mathrm{ab}}$ & $4.6 \pm 2.73^{\mathrm{bcd}}$ & $4.2 \pm 4.19^{\mathrm{b}}$ \\
\hline ICARDA-10 & $24.8 \pm 3.88^{\mathrm{abc}}$ & $32.3 \pm 7.05^{\mathrm{abc}}$ & $26.5 \pm 8.01^{\mathrm{bc}}$ & $18.7 \pm 6.86^{\mathrm{ab}}$ & $20.2 \pm 9.18^{\mathrm{bcd}}$ & $12.6 \pm 5.72^{\mathrm{b}}$ & $30.1 \pm 9.57^{\mathrm{abcd}}$ & $10.0 \pm 4.68^{\mathrm{ab}}$ & $3.5 \pm 0.84^{\mathrm{cd}}$ & $5.0 \pm 4.20^{\mathrm{b}}$ \\
\hline ICARDA-11 & $9.2 \pm 6.65^{\mathrm{c}}$ & $10.3 \pm 6.62^{\mathrm{bc}}$ & $31.1 \pm 4.80^{\mathrm{bc}}$ & $9.8 \pm 2.85^{\mathrm{c}}$ & $45.0 \pm 9.01^{\mathrm{ab}}$ & $28.5 \pm 5.91^{\mathrm{ab}}$ & $11.0 \pm 8.79^{\mathrm{cd}}$ & $16.1 \pm 5.88^{\mathrm{ab}}$ & $11.0 \pm 0.97^{\mathrm{abcd}}$ & $1.9 \pm 2.46^{\mathrm{b}}$ \\
\hline ICARDA-12 & $21.7 \pm 10.39^{\mathrm{bc}}$ & $22.4 \pm 11.90^{\mathrm{abc}}$ & $29.4 \pm 12.36^{\mathrm{bc}}$ & $23.3 \pm 5.45^{\mathrm{ab}}$ & $24.0 \pm 2.05^{\mathrm{bcd}}$ & $23.9 \pm 17.30^{\mathrm{ab}}$ & $14.9 \pm 6.08^{\mathrm{bcd}}$ & $12.9 \pm 5.03^{\mathrm{ab}}$ & $9.1 \pm 1.51^{\text {abcd }}$ & $3.8 \pm 1.28^{\mathrm{b}}$ \\
\hline ICARDA-13 & $34.8 \pm 3.21^{\mathrm{ab}}$ & $38.0 \pm 2.97^{\mathrm{ab}}$ & $40.6 \pm 11.88^{\mathrm{abc}}$ & $25.1 \pm 6.51^{\mathrm{ab}}$ & $37.6 \pm 14.49^{\mathrm{abcd}}$ & $1.7 \pm 28.43^{\mathrm{b}}$ & $8.7 \pm 0.66^{\mathrm{d}}$ & $1.7 \pm 5.65^{\mathrm{b}}$ & $9.5 \pm 1.92^{\text {abcd }}$ & $6.0 \pm 3.66^{\mathrm{ab}}$ \\
\hline ICARDA-14 & $23.4 \pm 4.02^{\mathrm{abc}}$ & $20.9 \pm 6.03 \mathrm{a}^{\mathrm{bc}}$ & $24.9 \pm 11.01^{\mathrm{bc}}$ & $8.9 \pm 3.79^{c}$ & $26.4 \pm 3.54^{\mathrm{bcd}}$ & $6.7 \pm 3.22^{\mathrm{b}}$ & $45.8 \pm 3.46^{\mathrm{a}}$ & $13.8 \pm 6.58^{\mathrm{ab}}$ & $6.8 \pm 4.69^{\text {abcd }}$ & $1.0 \pm 1.47^{\mathrm{b}}$ \\
\hline ICARDA-15 & $11.4 \pm 5.94^{\mathrm{bc}}$ & $10.9 \pm 8.25^{\mathrm{bc}}$ & $38.2 \pm 10.83^{\mathrm{abc}}$ & $19.5 \pm 5.05^{\mathrm{ab}}$ & $38.8 \pm 14.32^{\text {abcd }}$ & $31.0 \pm 19.25^{\mathrm{ab}}$ & $39.4 \pm 11.46^{\mathrm{abc}}$ & $2.7 \pm 0.10^{\mathrm{b}}$ & $14.1 \pm 4.68^{\mathrm{a}}$ & $1.0 \pm 2.19^{\mathrm{b}}$ \\
\hline $1385-13$ & $27.3 \pm 15.10^{\mathrm{abc}}$ & $27.9 \pm 15.91^{\mathrm{abc}}$ & $17.8 \pm 1.02^{\mathrm{c}}$ & $27.1 \pm 6.87^{\mathrm{ab}}$ & $17.0 \pm 5.23^{\mathrm{cd}}$ & $37.6 \pm 13.55^{\mathrm{ab}}$ & $12.0 \pm 1.89^{\mathrm{cd}}$ & $24.0 \pm 7.84^{\mathrm{a}}$ & $5.2 \pm 2.38^{\mathrm{abcd}}$ & $9.9 \pm 4.15^{\mathrm{ab}}$ \\
\hline NGUZO & $8.3 \pm 2.40^{\mathrm{c}}$ & $25.5 \pm 15.33^{\mathrm{abc}}$ & $24.0 \pm 4.25^{\mathrm{bc}}$ & $28.0 \pm 9.96^{\mathrm{ab}}$ & $56.2 \pm 8.24^{\mathrm{a}}$ & $43.2 \pm 16.18^{\mathrm{ab}}$ & $15.7 \pm 6.53^{\text {bcd }}$ & $10.5 \pm 5.05^{\mathrm{ab}}$ & $12.6 \pm 1.16^{\mathrm{abc}}$ & $4.4 \pm 7.19^{b}$ \\
\hline $1512-5$ & $10.8 \pm 4.33^{\mathrm{bc}}$ & $7.8 \pm 2.19^{\mathrm{c}}$ & $32.9 \pm 0.73^{\mathrm{bc}}$ & $11.6 \pm 4.28^{\mathrm{ab}}$ & $29.6 \pm 17.61^{\text {abcd }}$ & $54.9 \pm 26.51^{\mathrm{a}}$ & $22.9 \pm 7.10^{\text {abcd }}$ & $8.2 \pm 3.17^{\mathrm{ab}}$ & $5.5 \pm 1.50^{\mathrm{abcd}}$ & $1.0 \pm 2.35^{\mathrm{b}}$ \\
\hline KARNE & $18.4 \pm 6.84^{\mathrm{abc}}$ & $20.9 \pm 7.98^{\mathrm{abc}}$ & $30.4 \pm 15.13^{\mathrm{bc}}$ & $18.8 \pm 10.49^{\mathrm{ab}}$ & $41.4 \pm 4.27^{\mathrm{abc}}$ & $40.5 \pm 14.05^{\mathrm{ab}}$ & $30.5 \pm 7.58^{\mathrm{abcd}}$ & $19.8 \pm 6.25^{\mathrm{ab}}$ & $10.3 \pm 4.47^{\text {abcd }}$ & $9.1 \pm 4.26^{\mathrm{ab}}$ \\
\hline SABINI & $28.1 \pm 3.34^{\mathrm{abc}}$ & $33.2 \pm 14.82^{\mathrm{abc}}$ & $67.3 \pm 5.84^{\mathrm{a}}$ & $13.6 \pm 8.24^{\mathrm{ab}}$ & $35.3 \pm 13.06^{\mathrm{abcd}}$ & $48.6 \pm 26.55^{\mathrm{ab}}$ & $41.9 \pm 9.61^{\mathrm{ab}}$ & $18.6 \pm 7.07^{\mathrm{ab}}$ & $6.8 \pm 2.72^{\mathrm{abcd}}$ & $2.3 \pm 1.72^{\mathrm{b}}$ \\
\hline
\end{tabular}

Any two means in a column whose SE values overlap are not different at $\quad \alpha=0.05$ by DMRT

${ }^{*}$ Means followed by the same letter in column are not significantly different at $(p \leq 0.05)$.

Table 3. Effect of stem rust infection on yield and yield components of barley genotypes

\begin{tabular}{|c|c|c|c|c|c|c|}
\hline & Yield (t ha $\left.{ }^{-1}\right)$ & \multirow[b]{2}{*}{ Season2 } & \multicolumn{2}{|l|}{1000 kernel g) } & \multicolumn{2}{|l|}{ Grain size } \\
\hline \multirow[b]{2}{*}{$\begin{array}{l}\text { Genotypes code/ } \\
\text { Name }\end{array}$} & Season1 & & Season 1 & Season2 & Season 1 & Season 2 \\
\hline & Mean \% Loss & Mean \% Loss & Mean \% Loss & Mean \%Loss & Mean \% Loss & Mean \% Loss \\
\hline ICARDA- 01 & $24.7 \pm 2.51^{\mathrm{bcd}}$ & $13.9 \pm 2.64^{\mathrm{abc}}$ & $2.5 \pm 1.61^{\mathrm{cd}}$ & $1.6 \pm 0.80^{\mathrm{a}}$ & $3.0 \pm 2.17^{\mathrm{e}}$ & $31.8 \pm 4.62^{\mathrm{ab}}$ \\
\hline ICARDA- 02 & $17.5 \pm 1.55^{\mathrm{bcd}}$ & $7.2 \pm 1.72^{\mathrm{c}}$ & $2.7 \pm 1.73^{\mathrm{cd}}$ & $3.8 \pm 0.69^{\mathrm{a}}$ & $2.6 \pm 1.37^{\mathrm{e}}$ & $11.2 \pm 5.47^{\mathrm{b}}$ \\
\hline ICARDA- 03 & $27.9 \pm 14.82^{\mathrm{abcd}}$ & $24.1 \pm 13.57^{\mathrm{abc}}$ & $10.8 \pm 5.71^{\mathrm{abcd}}$ & $6.5 \pm 5.17^{\mathrm{a}}$ & $14.1 \pm 7.36^{\mathrm{de}}$ & $24.1 \pm 8.21^{\mathrm{ab}}$ \\
\hline ICARDA- 04 & $17.1 \pm 9.57^{\mathrm{bcd}}$ & $16.6 \pm 2.23^{\mathrm{abc}}$ & $9.2 \pm 4.50^{\mathrm{abcd}}$ & $2.4 \pm 1.38^{\mathrm{a}}$ & $21.4 \pm 6.67^{\text {cde }}$ & $34.2 \pm 14.98^{\mathrm{ab}}$ \\
\hline ICARDA- 05 & $14.4 \pm 2.62^{\mathrm{bcd}}$ & $8.2 \pm 4.13^{b c}$ & $10.2 \pm 4.13^{\mathrm{abcd}}$ & $1.8 \pm 3.05^{\mathrm{a}}$ & $34.6 \pm 6.21^{\mathrm{abcde}}$ & $36.4 \pm 10.77^{\mathrm{ab}}$ \\
\hline ICARDA- 06 & $21.9 \pm 8.23^{\mathrm{bcd}}$ & $20.9 \pm 6.69^{\mathrm{abc}}$ & $7.8 \pm 2.66^{\mathrm{abcd}}$ & $1.9 \pm 1.80^{\mathrm{a}}$ & $21.2 \pm 14.89^{\text {cde }}$ & $49.5 \pm 4.99^{\mathrm{a}}$ \\
\hline ICARDA -07 & $19.0 \pm 3.94^{\mathrm{bcd}}$ & $22.0 \pm 6.32^{\mathrm{abc}}$ & $8.0 \pm 2.93^{\mathrm{abcd}}$ & $1.7 \pm 1.71^{\mathrm{a}}$ & $29.0 \pm 14.95^{\text {bcde }}$ & $20.4 \pm 7.28^{\mathrm{b}}$ \\
\hline ICARDA- 08 & $53.8 \pm 17.50^{\mathrm{a}}$ & $8.1 \pm 1.77^{\mathrm{bc}}$ & $1.7 \pm 1.91^{\mathrm{d}}$ & $5.3 \pm 1.65^{\mathrm{a}}$ & $29.3 \pm 16.76^{\text {bcde }}$ & $30.0 \pm 3.54^{\mathrm{ab}}$ \\
\hline ICARDA- 09 & $15.2 \pm 8.64^{\mathrm{bcd}}$ & $14.3 \pm 4.21^{\mathrm{abc}}$ & $5.8 \pm 1.88^{\mathrm{bcd}}$ & $0.7 \pm 1.20^{\mathrm{a}}$ & $34.5 \pm 16.16^{\mathrm{abcde}}$ & $13.6 \pm 7.19^{\mathrm{b}}$ \\
\hline ICARDA- 10 & $22.6 \pm 11.97^{\mathrm{bcd}}$ & $27.6 \pm 5.89^{\mathrm{ab}}$ & $7.3 \pm 1.51^{\mathrm{abcd}}$ & $2.5 \pm 2.44^{\mathrm{a}}$ & $35.9 \pm 17.25^{\mathrm{abcde}}$ & $29.9 \pm 12.64^{\mathrm{ab}}$ \\
\hline ICARDA -11 & $24 . .2 \pm 5.64^{\mathrm{bcd}}$ & $25.7 \pm 11.43^{\mathrm{abc}}$ & $5.2 \pm 0.17^{\mathrm{bcd}}$ & $3.4 \pm 2.15^{\mathrm{a}}$ & $29.3 \pm 21.47^{\text {bcde }}$ & $37.9 \pm 7.91^{\mathrm{ab}}$ \\
\hline ICARDA -12 & $6.9 \pm 1.98^{\mathrm{d}}$ & $14.6 \pm 7.93^{\mathrm{abc}}$ & $2.4 \pm 1.55^{\mathrm{cd}}$ & $2.2 \pm 0.08^{\mathrm{a}}$ & $45.3 \pm 15.97^{\mathrm{abcd}}$ & $17.9 \pm 8.14^{\mathrm{b}}$ \\
\hline ICARDA- 13 & $15.3 \pm 2.64^{\mathrm{bcd}}$ & $20.6 \pm 14.54^{\mathrm{abc}}$ & $10.7 \pm 5.39^{\mathrm{abcd}}$ & $5.7 \pm 3.06^{\mathrm{a}}$ & $42.9 \pm 19.13^{\mathrm{abcd}}$ & $16.6 \pm 9.91^{\mathrm{b}}$ \\
\hline ICARDA- 14 & $16.5 \pm 3.84^{\mathrm{bcd}}$ & $9.0 \pm 6.05^{\mathrm{bc}}$ & $5.5 \pm 2.97^{\mathrm{bcd}}$ & $4.6 \pm 3.26^{\mathrm{a}}$ & $30.2 \pm 24.21^{\mathrm{bcde}}$ & $25.8 \pm 4.47^{\mathrm{ab}}$ \\
\hline ICARDA- 15 & $29.8 \pm 11.21^{\mathrm{abcd}}$ & $15.4 \pm 7.72^{\mathrm{abc}}$ & $7.2 \pm 3.01^{\mathrm{abcd}}$ & $6.0 \pm 3.19^{\mathrm{a}}$ & $36.3 \pm 22.79^{\mathrm{abcde}}$ & $26.0 \pm 14.03^{\mathrm{ab}}$ \\
\hline $1385-13$ & $14.0 \pm 7.46^{\mathrm{cd}}$ & $32.3 \pm 7.38^{\mathrm{a}}$ & $11.5 \pm 2.59^{\mathrm{abc}}$ & $6.6 \pm 3.69^{\mathrm{a}}$ & $56.4 \pm 12.68^{\mathrm{abc}}$ & $22.8 \pm 8.53^{\mathrm{ab}}$ \\
\hline NGUZO & $42.1 \pm 8.24^{\mathrm{ab}}$ & $5.3 \pm 3.88^{\mathrm{c}}$ & $9.4 \pm 3.00^{\mathrm{abcd}}$ & $2.9 \pm 0.72^{\mathrm{a}}$ & $29.1 \pm 26.66^{\text {bcde }}$ & $29.0 \pm 5.61^{\mathrm{ab}}$ \\
\hline $1512-5$ & $40.6 \pm 15.18^{\mathrm{ab}}$ & $9.6 \pm 5.34^{\mathrm{bc}}$ & $14.5 \pm 5.24^{\mathrm{ab}}$ & $5.2 \pm 1.70^{\mathrm{a}}$ & $69.3 \pm 7.82^{\mathrm{a}}$ & $12.4 \pm 2.90^{\mathrm{b}}$ \\
\hline KARNE & $27.3 \pm 8.66^{\mathrm{bcd}}$ & $21.3 \pm 12.53^{\mathrm{abc}}$ & $10.6 \pm 1.76^{\mathrm{abcd}}$ & $2.3 \pm 1.28^{\mathrm{a}}$ & $58.5 \pm 17.57^{\mathrm{ab}}$ & $26.5 \pm 11.40^{\mathrm{ab}}$ \\
\hline SABINI & $15.8 \pm 6.71^{\mathrm{bcd}}$ & $13.6 \pm 3.53^{\mathrm{abc}}$ & $14.8 \pm 3.78^{\mathrm{a}}$ & $1.6 \pm 0.80^{\mathrm{a}}$ & $41.7 \pm 21.64^{\mathrm{abcd}}$ & $32.5 \pm 1.72^{\mathrm{ab}}$ \\
\hline
\end{tabular}

Any two means in a column whose SE values overlap are not different at $\alpha=0.05$ by DMRT.

"Means followed by the same letter in a column are not significantly different at ( $p \leq 0.05)$. 